Humaniora. Czasopismo Internetowe

$\operatorname{Nr} 3(27) / 2019$, ss. 45-59

\author{
ANTONI TORZEWSKI \\ Uniwersytet Kazimierza Wielkiego w Bydgoszczy \\ Wydział Nauk Społecznych i Administracji, Instytut Filozofii \\ e-mail: antoni.torzewski@gmail.com \\ ORCID: 0000-0003-3299-783X
}

\title{
Religia a rozum \\ w świetle filozofii Gianniego Vattimo
}

\begin{abstract}
The reason's emancipation ideal present in the Enlightenment is, according to Gianni Vattimo, convergent with a part of the history of the presence of religion in philosophical reflection. However regress of religious thought along with growth of the "power" of reason ended because of self-abolition of reason in its emancipation. Thus religion returned to the philosophical thought and is broadly considered. Of course it is not the same religion but different - separated from classic metaphysics. For religion appears as a discourse focused not on reason, and at the same time not claiming the right to be a mirror of the absolute truth, but as focused on interpretation and secularization. In accordance with Vattimo's thought, I will try to show, what abandonment of metaphysics is about and if it is also an abandonment of reason. Furthermore I will present the contemporary place of hermeneutical reflection on religion.
\end{abstract}

Keywords: philosophy of religion, reason, religion, Vattimo, hermeneutics, weak thought

\section{Wstęp}

Delacja rozumu i religii to problem szeroko omawiany w filozofii. Jednym ze współczesnych filozofów zajmujących się tym tematem jest włoski myśliciel Gianni Vattimo. W niniejszym tekście postaram się ukazać zarys jego koncepcji dotyczącej relacji rozumu i religii. Najwyraźniej będzie to można przedstawić za pomocą dwóch szczególnie ważnych dla niego pojęć - nowoczesności i ponowoczesności. W nowoczesności bowiem rozum jest z religią skonfliktowany 
i prowadzi do jej regresu, natomiast ponowocześnie konfliktu tego już nie ma ze względu na krytykę rozumu, metafizyki i prawdy absolutnej przeprowadzonej nie tylko przez Vattima, ale przez całą tradycję rozpoczynającą się od Nietzschego, poprzez Heideggera i Gadamera, kończąc na filozofach współczesnych, takich jak: Rorty, Lyotard czy właśnie prezentowany Vattimo. Niniejszy tekst podzielony będzie na dwie części: nowoczesność i ponowocześność. W części pierwszej postaram się zaprezentować, jak włoski myśliciel postrzega nowoczesność, a zatem rozum i jego relację do religii. Natomiast w części drugiej zrekonstruuję krytykę nowoczesności i jej przezwyciężenie (w sensie Verwindung) oraz ponowoczesną relację rozumu i religii. Na koniec ukażę, jak wedle Vattima jawi się ponowoczesne chrześcijaństwo, a także podejmę refleksję nad miejscem, jakie zajmuje w nim Bóg.

\section{Nowoczesność}

Epoka nowoczesna to, wedle Vattima, epoka konkretnie pojętego rozumu. Włoski filozof wskazuje przede wszystkim na jego obiektywne roszczenie, które następnie poddaje krytyce z punktu widzenia ponowoczesności. Jak jednak rozumieć to nowoczesne pojęcie rozumu? Wydaje się, że najbardziej wyraźne stanie się ono dzięki ukazaniu związków rozumu z metafizyką, prawdą i nauką. Nowoczesny sposób myślenia zorientowany na rozum realizujący ideał obiektywnego poznania wyraża się, wedle Vattimo, w metafizyce obecności, która traktuje Byt jako to, co jest (obecne) i zatem ahistoryczne. Takiemu rozumieniu Bytu odpowiada epistemologiczny ideał kartezjanizmu, tj. dążenie do uchwycenia prawd pewnych jako funadmentów rozumienia ${ }^{1}$. Właśnie to fundamentalistyczne (w znaczeniu, że istnieje pewien niekwestionowalny fundament stanowiący źródło myślenia) nastawienie charakteryzuje, wedle Vattima, całą nowoczesność i jest również związane z rozwojem nauk przyrodniczych, które połączyły obiektywne roszczenie rozumu z metodą naukową jako niezawodną w osiąganiu wniosków pewnych. Pojęcie rozumu w nowoczesności łączy się zatem przede wszystkim z metafizyką obecności, ideą pewności, istnieniem fundamentu - albo pewnej instancji, dzięki której zyskujemy pewność - oraz naukami przyrodniczymi. Warto zaznaczyć, że to właśnie dzięki ahistorycznemu charakterowi Bytu i obiektywnemu ideałowi rozumu możliwe jest zdystansowanie się filozofa w stosunku do jego przedmiotu badań. W nowoczesności dominuje więc nastawienie zdystansowanego obserwatora rzeczywistości poszukującego prawdy. Tym samym filozofia nowoczesna realizuje grecki ideał theorein, który wyraził już Pitagoras:

[...] życie jest podobne do święta ludowego; jedni idą na nie, żeby wziąć udział w igrzyskach, inni, żeby handlować, a jeszcze inni, i to najlepsi, jako widzowie; po-

\footnotetext{
${ }^{1}$ Por. R. Descartes, Medytacje o pierwszej filozofii, tłum. J. Hartman, Kraków 2004.
} 
dobnie w życiu, jedni są niewolnikami sławy, inni władzy, inni natomiast są filozofami i szukają prawdy².

Oczywiście takiego rodzaju dystans pozwala na oglądanie całości i wyrażanie sądów posiadających roszczenie do (absolutnej) prawdziwości i obiektywności - obserwator bowiem jest zdystansowany, niezaangażowany w to, co opisuje. Podsumowaniem nowoczesności jest husserlowski ideał wiedzy bezzałożeniowej, pewnej, stanowiącej ścisłą naukę ${ }^{3}$ Używane bowiem przez Husserla pojęcie epoché wyraża właśnie ów całkowity, totalny dystans badacza wobec przedmiotu badania.

Związany z taką wizją rozumu jest ideał postępu, który zaczął być obecny na poważnie w filozofii od oświecenia. Wystarczy wskazać w tym miejscu na rozwój Ducha w systemie Hegla ${ }^{4}$ czy postęp moralny opisywany w dziele Wychowanie rodzaju ludzkiego autorstwa Lessinga ${ }^{5}$. Jak pisze Tadeusz Gadacz, filozofowie oświecenia „[... ] uważali, że im bardziej jesteśmy istotami racjonalnymi, tym bardziej oddalamy się od Boga, a religię wiary w Boga zastępuje »religia wiary w postęp rozumu «”6. Ideał postępu rozumu nie zatracił się jednak wraz z końcem epoki oświecenia, lecz pozostał silnie obecny również w nowoczesności. Pojęcie postępu musi natomiast prowadzić do rozważań na temat historii. W nowoczesności historia jest jednolita i stanowi dzieje przyrostu-postępu dzięki możliwości dystansu wobec rzeczywistości czy przedmiotu badań. Historia zatem jest jedna oraz odzwierciedla faktyczny i obiektywny stan rzeczy. Ponadto jest również dziejami przybliżania się do prawdy (obiektywnej). Vattimo charakteryzuje nowoczesność „,[...] jako epokę zdominowaną przez historię myśli jako progresywnego »oświecenia«, dojrzewającego na zasadzie coraz pełniejszego przywłaszczenia i ponownego zawłaszczenia »fundamentów « określanych często także jako źródła”7. Nowoczesność to epoka „metanarracji”8 czy „wielkich opowieści” - teorii, które chcą rozumowo wyjaśnić wszystko. Te „metanarracje” fundowane na rozumie, który nieustannie się rozwija, implikują także ideę sekularyzacji.

Sekularyzacja pojmowana jako nowoczesność jest [...] „wartością”, która dominuje w danej epoce i kieruje jej świadomością, przede wszystkim w sensie wiary w postęp (która jest jednocześnie wiarą zsekularyzowaną i wiarą w sekularyzację) ${ }^{9}-$ pisze Vattimo.

2 D. Laertios, Żywoty i poglądy słynnych filozofów, tłum. K. Leśniak, I. Krońska, B. Kupis, W. Olszewski, Warszawa 1984, s. 467.

${ }^{3}$ Por. E. Husserl, Filozofia jako ścisła nauka, tłum. W. Galewicz, Warszawa 1992.

${ }^{4}$ Por. G.W.F. Hegel, Fenomenologia ducha, tłum. A. Landman, Warszawa 2002.

${ }^{5}$ Por. G.E. Lessing, Wychowanie rodzaju ludzkiego, tłum. H. Kahanova, w: G.E. Lessing, Dzieła wybrane, tom III, Warszawa 1959.

6 T. Gadacz, Rozumowe poznawanie Boga, Bydgoszcz 2000, s. 13.

7 G. Vattimo, Koniec nowoczesności, tłum. M. Surma-Gawłowska, Kraków 2006, s. 2.

${ }^{8}$ Por. F. Lyotard, Kondycja ponowoczesna, tłum. M. Kowalska, J. Migasiński, Warszawa 1997.

${ }^{9}$ G. Vattimo, Koniec nowoczesności, s. 93. 
Widzimy więc wyraźnie, jak ideał postępu rozumu łączy się z sekularyzacją. Pojęcie to jednak ma aktualnie wiele znaczeń i może być rozpatrywane w wielu aspektach. Posłużę się tutaj rozróżnieniami proponowanymi przez Charlesa Taylora i Tomasza Węcławskiego. Taylor dzieli sekularyzację na polityczną i społeczną. Pierwsza będzie oznaczać „[...] proces, dzięki któremu państwo potwierdza swoją niezależność od religii” ${ }^{0}$, natomiast druga to „destrukcja wpływu religii w praktykach społecznych i w kierowaniu życiem indywiduum”11. Innymi słowy, sekularyzacja polityczna dotyczy państwa jako instytucji i jego stosunku do religii, a sekularyzacja społeczna odnosi się do społecznego (społeczeństwo jest tu rozumiane jako zbiór indywiduów) nastawienia do religii w ogóle. Sekularyzacja w kontekście nowoczesnym, jaki tu rozważamy, będzie rozumiana zatem przede wszystkim w tym drugim sensie, tj. jako sekularyzacja społeczna. Podobne, acz skupiające się na nieco innym aspekcie, rozróżnienie proponuje Węcławski. Społeczność religijna i polityczna pozostają wedle niego w jednym z trzech typów konfliktów ${ }^{12}$. Ten zaś rodzaj, któremu odpowiada nowoczesna sekularyzacja, określa Węcławski jako konflikt wartości przyjmowanych przez obie grupy (religijną i świecką) ${ }^{13}$. Vattimo natomiast definiuje sekularyzację jako „proces »dryfowania«, który odsunął nowoczesną laicką cywilizację od jej sakralnych początków”14. Podsumowując, nowoczesna sekularyzacja nie dotyczy przede wszystkim państwa i jego stosunku do religii, lecz nastawienia do niej poszczególnych osób, desakralizacji czy panującego klimatu opinii dotyczącego religii. Klimat ten kreowany jest w tym kontekście przez dominujący ideał rozumu, który wchodzi z religią w konflikt. Wartością jest bowiem naukowość i obiektywność, której religia nie posiada i jako taka jest nieweryfikowalna, co sprawia, że nastawienie do niej nie jest bynajmniej przychylne. Rozum zatem prowadzi do krytyki nie tylko religii, ale również wszystkiego, co nienaukowe, nieracjonalne (w sensie racjonalności pojętej nowocześnie). Z tego powodu mamy również do czynienia z ukuciem pojęć takich jak „demitologizacja”15, „desakralizacja” czy „odczarowanie”. We wszystkich tych pojęciach zawarte jest dążenie do usunięcia mitu, sacrum, czy „magii”, a tym samym do uczynienia świata bardziej „rozumnym”, tj. takim, który można opisać za pomocą samego tylko rozumu. Religia w epoce nowoczesnej, wedle Vattimo, znajduje się więc w stanie regresu.

Połączenie rozumu i nauki to jednak tylko jedna z dwóch dróg obecnych w nowoczesności prowadzących do zaniku religii. Kolejnym czynnikiem, na

${ }^{10}$ Ch. Taylor, J. Maclure, Secularism and Freedom of Conscience, Harvard 2011, s. 15. (wszystkie fragmenty dzieł nietłumaczonych na język polski w przekładzie autora).

11 Ibidem, s. 16.

12 Por. T. Węcławski, Wspólny świat religii, Kraków 1995, s. 246.

${ }^{13}$ Por. ibidem, s. 248.

${ }^{14}$ G. Vattimo, Belief, tłum. D. Webb, Stanford UP 1999, s. 41.

${ }^{15}$ Por. Th. Adorno, M. Horkheimer, Dialektyka oświecenia, tłum. M. Łukasiewicz, M.J. Siemek, Warszawa 2010. 
który wskazuje Vattimo, jest bowiem racjonalizacja samej religii i traktowanie Boga w kategoriach metafizyki obecności, jako fundamentu. Dążenie ludzi wierzących do prawdy, która zawiera się w religii, również powoduje jej regres w tym sensie, że religia przestaje być religią. Wyraz takiego nastawienia mogą stanowić np. oświeceniowe koncepcje moralnej istoty religii rozwijane m.in. przez Lessinga $^{16}$, wczesnego Hegla ${ }^{17}$ czy Kanta $^{18}$ (chociaż akurat przypadek Kanta może być dyskusyjny ${ }^{19}$ ). Pojmowanie religii w kategoriach samego rozumu (jak głosi tytuł rozprawy filozofa z Królewca) i traktowanie Boga jako fundamentu wiedzy pewnej nawet w większym stopniu przyczynia się, wedle Vattima, do nowoczesnego regresu religii. „Bóg umiera - pisze Vattimo - zabity przez religijność, przez rządzę prawdy, którą jego wierni zawsze kultywowali, a która teraz doprowadziła ich do odkrycia, że On także był błędem, bez którego można się już teraz obejść”’20. Jak zobaczymy, włoski filozof nie propaguje ateizmu (w sensie tezy o nieistnieniu Boga), ale interpretuje Boga i jego rolę w zupełnie inny sposób. Błąd natomiast, o którym mówi, odnosi się właśnie do pojmowania Boga jako metafizycznej podstawy wiedzy pewnej. Dla Vattima jednak wszelki fundamentalizm (w omawianym wyżej sensie jako przeświadczenie o istnieniu fundamentu wiedzy) jest nieporządany i nieuzasadniony, zawsze bowiem prowadzi do przemocy, o czym będzie mowa w kolejnej części.

\section{Ponowoczesność}

W epoce ponowoczesności, za której przedstawiciela można uznać Gianniego Vattima, sytuacja religii wygląda całkiem inaczej niż w nowoczesności. Rozum bowiem, wypierający religię, przeżywa kryzys. „Jeśli prawdą jest, że religia jawi się obecnie jako wymaganie głębokie, a przy tym filozoficznie wiarygodne, jest to zasługą także, a może przede wszystkim, ogólnego rozpadu pewności racjonalistycznych, którymi żył człowiek nowoczesny”"21 - pisze Vattimo. Tak jak w poprzedniej części postaram się ukazać pojęcie rozumu poprzez jego związek z metafizyką, prawdą i nauką, lecz pojętymi już w kategoriach ponowoczesnych. Jak zaznaczyliśmy, nowoczesny rozum wiązał się ściśle z metafizyką obecności. W epoce ponowoczesnej natomiast, dzięki Nietzschemu i Heideggerowi, owa metafizyka (albo używając języka Heideggera - onto-teo-logia) została zdyskredytowana ${ }^{22}$, ponieważ „stara się

${ }^{16}$ Por. G.E. Lessing, Wychowanie rodzaju ludzkiego.

${ }_{17}$ Por. G.W.F. Hegel, Życie Jezusa, tłum. M. J. Siemek, Warszawa 1995.

${ }_{18}$ Por. I. Kant, Religia w obrębie samego rozumu, tłum. A. Bobko, Kraków 1993.

${ }_{19}$ Por. np. M. Chlewicki, Kant a problem filozofii religii, Bydgoszcz 2012.

${ }^{20}$ G. Vattimo, Koniec nowoczesności, s. 156.

${ }^{21}$ G. Vattimo, Ślad śladu, tłum. E. Łukaszyk, w: J. Derrida, G. Vattimo, Religia, Warszawa 1999, s. 109.

${ }^{22}$ Habermas w dziele Przyszłość natury ludzkiej również zauważa kres metafizyki w ponowoczesności, co wiąże z niemożliwością odpowiedzi na pytanie o dobre życie. Skoro 
ona w jednym geście zapanować nad rzeczywistością, rozpoznając (bądź łudząc się co do tego) pierwszą zasadę, od której wszystko zależy (dostarczając w ten sposób sobie samej iluzorycznej władzy nad wydarzeniami). Postępując w tej kwestii za Nietzschem, Heidegger pokazał, że rozpatrywanie bycia w kategoriach podstawy, a rzeczywistości jako racjonalnego systemu przyczyn i skutków to tylko sposób, by na całość bycia rozszerzyć model »naukowej « obiektywności”23. Ponadto Vattimo zwraca uwagę na to, że byt (czy może należałoby powiedzieć „bycie”) nie ma charakteru ahistorycznego, nie jest tym, co jest, ale tym, co się wydarza ${ }^{24}$. Jako taki zaś byt nie może być przedmiotem wiedzy pewnej, ale interpretacji. Na tej podstawie z jednej strony krytykuje się klasyczną definicję prawdy - może ona mieć zastosowanie jedynie w obrębie paradygmatu, „każde stwierdzenie - zauważa Vattimo - może zostać zweryfikowane lub sfalsyfikowane jedynie w obrębie jakiegoś horyzotnu (otwarcia, paradygmatu, języka), który z kolei sam nie może być zweryfikowany”25 - z drugiej zaś odchodzi się od niej na rzecz hermeneutycznej koncepcji prawdy jako otwierania się horyzontów. Jak pisze Vattimo:

[...] prawda jako otwarcie horyzontów, w obrębie których jawi się to, co prawdziwe i fałszywe w sensie propozycji, wydarzała się zawsze, skoro stanowi warunek możliwości wszelkiego naszego świadomego działania i myślenia; nie będąc jednakowoż strukturą transcendentalną (z wyżej wymienionych powodów: nie jest stabilna i dana raz na zawsze, jak przedmioty które nam udostępnia) ani ahistoryczną, jest czymś, co się wydarza $[\ldots]^{26}$.

Stwierdzenie, że prawda i byt mają charakter dziejowy niszczy nowoczesne przeświadczenie o istnieniu fundamentu naszego poznania. W ponowoczesności nie ma już ostatecznej instancji, zawsze takiej samej i obecnej, do której możemy się odwołać, aby określić słuszność naszego poznania i naszych twierdzeń. Tym samym w koncepcji Vattima zrywa się z ukutym w nowoczesności związkiem rozumu, który może dojść do obiektywnej prawdy z naukami przyrodniczymi. Za-

nie ma fundamentu, ani religia, ani metafizyka, ani nic innego nie może jednoznacznie i w sposób pewny stwierdzić, ,jak żyć”. „Dopóki filozofia wierzyła - pisze niemiecki filozof - że może wypowiadać się w sposób pewny o całości przyrody i historii, rozporządzała rzekomo stałymi ramami, zdolnymi ogarnąć ludzkie życie jednostek i wspólnot. Budowa kosmosu i ludzka natura, stadia dziejów i historii zbawienia dostarczały faktów nasyconych wymową normatywną, podsuwających, jak się zdawało, także wskazówki co do właściwego życia”. J. Habermas, Przyszłość natury ludzkiej, tłum. M. Łukasiewicz, Warszawa 2003, ss. 9-10. Pytanie, na jakie stara odpowiedzieć się Habermas, dotyczy możliwości postmetafizycznych propozycji „dobrego życia”. Wydaje się, że Vattimo również podejmuje ten problem i upatruje owej propozycji w chrześcijaństwie, co postaram się ukazać.

${ }^{23}$ G. Vattimo, Społeczeństwo przejrzyste, tłum. M. Kamińska, Wrocław 2006, s. 21.

${ }^{24}$ To stwierdzenie jest kluczowe dla zrozumienia koncepcji „słabego bycia”, które pojawia się w ramach „słabej myśli” propagowanej przez Vattimo.

${ }^{25}$ G. Vattimo, After onto-theology: philosophy between science and religion, w: M. Wrathall (red.), Religion after Metaphisics, Cambridge University Press 2003, s. 34.

${ }^{26}$ G. Vattimo, Poza interpretacjq, tłum. K. Kasia, Kraków 2011, s. 27. 
uważmy, że ponowoczesność nie jest li tylko krytyką nowoczesności - metafizyki obecności, prawdy absolutnej, nauk przyrodniczych i istnienia fundamentu, ale pozytywnie proponuje inną drogę, skupioną wokół (słabej) ontologii bycia i prawdy hermeneutycznej nieopartej na żadnym fundamencie. Powracając do przywołanej już wyżej Pitagorejskiej metafory, filozof ponowoczesny uznający wydarzeniowy charakter bytu nie będzie bynajmniej wywyższanym przez Pitagorasa zdystansowanym obserwatorem rzeczywistości, ale zaangażowanym jej uczestnikiem. Całkowity czy totalny dystans nie jest bowiem możliwy ze względu na dziejowy charater samego obserwatora. „Nie można - pisze Vattimo - (nie dlatego, że się nie powinno, ale dlatego, że się nie da) w sposób sztuczny uzyskać (po krytyce ideologii, po Nietzscheańskim historycyzmie) nastawienia »naturalnego «”27. Sama metafizyka, krytykowana przez włoskiego filozofa, musi prowadzić do wniosków o nieobiektywnym charakterze badacza, bowiem „metafizyka, zaczynająca od idei, że prawda to obiektywność, kończy na »odkryciu«, że obiektywność zakładana jest przez podmiot, który z kolei staje się manipulowalnym przedmiotem" ${ }^{28}$. Z tego punktu widzenia wychodzi też Gadamer, który poprzez rehabilitację przedsądów zawartą w Prawdzie i metodzie ${ }^{29}$, zrywa właśnie z tą tradycją zdystnasowania. Na gruncie hermeneutyki gadamerowskiej można by również przeprowadzić krytykę Husserlowskiego pojęcia epoché, postulatu zerwania z przedsądami, z którymi, wedle Gadamera, zerwać nie można ${ }^{30}$.

Zarówno Heideggerowskie ujawienie prestruktury rozumienia, jak i Gadamerowska teoria przedsądów prowadzą do podważenia idei obiektywnego charakteru wiedzy. Przy odpowiedniej interpretacji, jaką zakłada Vattimo, koncepcję Gadamera można również połączyć z teorią paradygmatów Kuhna wyłożoną w Strukturze rewolucji naukowych ${ }^{31}$, co pozwala na stwierdzenie, że metafizyka i prymat rozumu obecne w nowożytności to tylko jedna z opowieści, jeden z paradygmatów. Podobnie rzecz ma się z historią, która w nowoczesności rozumiana była jako jednolita i obiektywna, a obecnie ,jest opowieścią, »jedną z wielu historii«”32. Dlatego też Vattimo nazywa ponowoczesność kresem historii oznaczającym „koniec koncepcji ludzkich dziejów jako włączonych w jednolity bieg, z przyznanym mu specyficznym sensem, który ujawniał się i był rozumiany jako sens emancypacji”33 oraz „koniec metafizyki w jej formie nowoczesnej, czyli zarazem koniec historyzmu [...]”34. Co jednak uważa Vattimo za przyczynę przejścia od jednolitej historii nowoczesności do pluralistycznej ponowoczesności?

${ }^{27}$ Ibidem, s. 100.

${ }^{28}$ G. Vattimo, After onto-theology..., s. 33.

${ }^{29}$ Por. H.-G. Gadamer, Prawda i metoda, tłum. B. Baran, Warszawa 2007.

${ }^{30}$ Por. ibidem, ss. 256-260.

${ }^{31}$ Por. T.S. Kuhn, Struktura rewolucji naukowych, tłum. H. Ostromęcka, Warszawa 2011.

${ }^{32}$ G. Vattimo, Koniec nowoczesności, s. 9.

${ }^{33}$ G. Vattimo, Postnowoczesność i kres historii, tłum. B. Stelmaszczyk, w: R. Nycz (red.), Postmodernizm. Antologia przekładów, Kraków 1998, s. 129.

${ }^{34}$ Ibidem, s. 134. 
Aby odpowiedzieć na to pytanie, użyję wspomnianych już wyżej pojęć demitologizacji, desakralizacji czy odczarowania związanych z ideałem emancypacji rozumu. Włoski filozof zwraca bowiem uwagę na paradoksalny charakter owego ideału, który dążąc do racjonalizacji i zerwania z mitem, musi w pewnym momencie sam siebie rozpoznać jako mit. „Demitologizacja - pisze Vattimo - w końcu obróciła się wobec samej siebie poprzez uznanie, że ideał eliminacji mitu też jest mitem”35. Natomiast „[...] odczarowanie to rozpoznanie, że nie istnieją obiektywne struktury, wartości, prawa, że wszystko jest ludzkim ustanowieniem i kreacją (przynajmniej w dziedzinie znaczenia)”36. Rozum prowadzi zatem niejako do zniesienia samego siebie, a przynajmniej do zniesienia swojego obiektywistycznego roszczenia. W tym też sensie historia przestaje być jednolita. Kluczowym stwierdzeniem określającym kształt ponowoczesności i stosunku tej epoki do historii jest Nietzscheańska konstatacja, że „prawdziwy świat stał się baśnią”37 - nie ma obiektywności rozumu (bo została zniesiona przez samą siebie), nie ma prawdy absolutnej (istnieje tylko wewnątrz paradygmatów). „Dotąd filozofowie wierzyli, że opisują świat, teraz trzeba go interpretować"38 - pisze Vattimo w Poza interpretacjq. Zdanie to wyraża właściwie cały sens ponowoczesności w ujęciu włoskiego filozofa.

Ukażę teraz, jak opisane wyżej dzieje rozumu (oraz związanych z nimi dziejami metafizyki, prawdy i nauki) wpłynęły na religię oraz jakie miejsce zajmuje ona w ponowoczesności. Innymi słowy, co dla religii implikuje ponowoczesna interpretacja rozumu? Tak jak w nowoczesności religia przeżywała regres z jednej strony poprzez paradygmat naukowy, z drugiej zaś poprzez metafizyczne pojęcie Boga, tak ponowoczesność otwiera na nowo możliwość religii.

Końcowi nowoczesności, a przynajmniej jej kryzysowi, towarzyszył również rozpad głównych teorii filozoficznych, które twierdziły, że zlikwidowały religię: pozytywistyczny scjentyzm, heglizm, a później marksistowski historyzm ${ }^{39}$ - pisze Vattimo.

Kryzys nowoczesności to, jak starałem się pokazać, kryzys rozumu, metafizyki i prawdy absolutnej, tj. myślenia systemowego ${ }^{40}$; odejście od jedności (do której tak dąży myślenie systemowe) na rzecz wielości, a także od prawdy na rzecz interpretacji. W tym sensie, wedle Vattima, prowadząca do ponowoczesności

[...] hermeneutyka przedstawia się jako myśl zasadniczo przyjazna religii, gdyż wraz ze swoją krytyką idei prawdy jako weryfikowalnej zgodności twierdzenia i rzeczy odbiera również podstawy racjonalistycznym, empirystycznym, pozytywistycznym, a nawet idealistycznym i marksistowkim negacjom możliwości doświadczenia religijnego ${ }^{41}$.

${ }^{35}$ G. Vattimo, After onto-theology..., s. 30.

${ }^{36}$ G. Vattimo, Społeczeństwo przejrzyste, s. 104.

${ }^{37}$ G. Vattimo, Koniec nowoczesności, s. 20.

${ }^{38}$ G. Vattimo, Poza interpretacjq, s. 24.

${ }^{39}$ G. Vattimo, Belief, s. 28.

${ }^{40}$ Por. G. Vattimo, Ślad śladu, s. 101.

${ }^{41}$ G. Vattimo, Poza interpretacją, s. 57. 
Wraz z hermeneutyczną krytyką prawdy absolutnej następuje rehabilitacja mitu. Mit bowiem to jedyne, co mamy ${ }^{42}$. Ponieważ „[... ] filozofia odkryła na nowo wiarygodność religii”43, w ponowoczesności następuje jej powrót. Jest to jednak już nieco inna religia.

Przede wszystkim powrót do religii, powrót do Boga nie może być rozumiany jako powrót do metafizycznego fundamentu ${ }^{44}$. Bóg bowiem, jako metafizyczny fundament, umarł ${ }^{45}$ - jak zauważa Nietzsche. Właśnie taką interpretację słów niemieckiego myśliciela proponuje Vattimo. „Bóg umarł” nie jest metafizyczną konstatacją stwierdzającą, że Bóg (już) nie istnieje, że go nie ma ${ }^{46}$, lecz interpretacją dziejów głoszącą, że nie istnieje fundament i prawda absolutna, „że wiara w Boga nie jest już potrzebna ani nawet »moralnie« możliwa - przynajmniej wiara w Boga tradycji onto-teologicznej” ${ }^{47}$. Chodzi więc o porzucenie Boga jako fundamentu, Boga metafizyki. Czy jednak możliwy jest powrót (albo zwrócenie się ku) do jakiegokolwiek innego Boga? Warto odwołać się w tym miejscu do niemieckiego myśliciela Rudolfa Otto i opisywanej przez niego kategorii świętości ${ }^{48}$. To, co święte (w tym kontekście Bóg) określane jest przez pojęcia numinosum, tremendum i fascians. Bóg nowoczesności, Bóg metafizyki, Bóg jako fundament zawiera w sobie wszystkie trzy aspekty, przy czym wydaje się, że najmniejszy nacisk kładzie się na element fascinans. W ponowoczesności natomiast poprzez „śmierć Boga” odziera się go zarówno z numinosum, jak i tremendum. To, co utożsamia Bóg, to Ottowskie fascinans, tj. to, co wzbudza podziw, fascynuje. Tak rozumiany Bóg jest jedynym, do którego można zwrócić się w ponowoczesności. Jako fascinans jednak Bóg może być jedynie przedmiotem naszego podziwu, nie zaś jakiejkolwiek wiedzy, nie może też stanowić fundamentu, tak jak było to możliwe w nowoczesności. Podejście ponowoczesnego wierzącego do Boga może być porównane z nastawieniem greckich sceptyków, którzy zakładali niemożliwość posiadania o nim wiedzy. Wydaje się jednak, że ponowoczesny wierzący nie byłby aż tak radykalny jak greccy sceptycy, tj. nie powstrzymałby się od wydawania jakichkolwiek sądów na jego temat, ponieważ dozwolone, w jego mniemaniu, byłyby interpretacje, które oczywiście nie roszczą sobie prawa do bycia odzwierciedleniem jakiejś prawdy absolutnej. Vattimo podąża właśnie taką drogą. Proponuje bowiem pewną interpretację postaci

${ }^{42}$ Por. ibidem, s. 65.

${ }^{43}$ G. Vattimo, Ślad śladu, s. 105.

${ }^{44}$ Por. ibidem, s. 103. Trafnie takie pojmowanie Boga uchwycił Henry Duméry: „[...] zaczyna nam on [Bóg - A.T.] służyć jako gwarant naszych twierdzeń bądź działań. Bóg jako strażnik naszych praw, miejsce naszych idei, punkt odniesienia dla naszych prawd - cóż za wspaniały fundament bezpieczeństwa, źródło spokoju sumienia, wyręka w długich i mozolnych poszukiwaniach”. H. Duméry, Problem Boga w filozofii religii, tłum. I. Kania, Kraków 1994, ss. 56-57, za: T. Gadacz, Rozumowe poznawanie Boga, s. 31.

${ }^{45}$ Por. F. Nietzsche, Wiedza radosna, tłum. L. Staff, Warszawa 1906, 125.

${ }^{46}$ Por. G. Vattimo, Poza interpretacjq, s. 17.

${ }^{47}$ Ibidem, s. 121.

${ }^{48}$ Por. R. Otto, Świętość, tłum. Bogdan Kupis, Wrocław 1993. 
Jezusa, a szczególną uwagę poświęca związanemu z nim pojęciu kenosis - uniżenia. Jezus nie jest oczywiście rozumiany przez Vattima jako metafizyczna podstawa, Bóg przez wielkie „B”, lecz bardziej jako właśnie ten uniżony bóg odarty ze swej metafizyczności, transcendencji z numinosum i tremendum ${ }^{49}$. Podkreślanym przez włoskiego filozofa sensem przesłania Jezusa nie jest zbawienie i śmierć za grzechy ludzi albo ustanowienie Kościoła, lecz, po pierwsze, przykazanie miłości (wokół którego jedynie oscylować ma ponowoczesne chrześcijaństwo), a po drugie kenosis, które Vattimo łączy z pojęciem sekularyzacji. Wedle jego interpretacji fakt uniżenia się Boga, jego zrezygnowania z własnej transcendencji czy zdemitologizowania się wskazuje na sekularny charakter samego chrześcijaństwa. Paradoksalnie (jeśli weźmiemy pod uwagę pogląd, że sekularyzacja to dążenie do całkowitego zniesienia religii) sekularyzacja staje się nie tyle przyjazna chrześcijaństwu, ile stanowi samo chrześcijaństwo ${ }^{50}$. Powtórzmy - chrześcijaństwo jest sekularyzacją. Świadczy o tym omówiony wyżej demitologizujący sens uniżającego się Boga. Sekularyzacja w tej interpretacji łączy się także z ponowoczesnością, bowiem przyczynia się do osłabiania „mocnych struktur” (takich jak systemy metafizyczne) ${ }^{51}$. Zarówno więc sekularyzacja, jak i fenomen kenosis wypełniają sens ponowoczesnego dążenia do ukazania braku prawdy absolutnej, ukazania, że „nie ma faktów, są tylko interpretacje”52, oraz do zerwania z przemocą ${ }^{53}$. Wszystkie „mocne struktury” bowiem, każda metafizyka, wszystko, co zakłada prawdę absolutną czy fundament, prowadzi do przemocy, „o ile jest ona [metafizyka - A.T.] myśleniem o wiecznej obecności bycia - jako o ostatecznym fundamencie, wobec którego można jedynie milczeć i, być może, doświadczać zachwytu - o tyle jest myśleniem opresyjnym: fundament, jeżeli jawi się z nieodwracalną oczywistością, nie pozostawiając miejsca na dalsze pytania, staje się niczym władza, która zakrywa i narzuca się, »nie udzielając wyjasnień«"54 - pisze włoski filozof. Ta znana ponowoczesna teza, że metafizyka rodzi przemoc $^{55}$, wygłaszana nie tylko przez Vattima, lecz także przez np. Foucaulta czy Lyotarda, wskazuje na źródło powstawania totalitaryzmów. Każda teoria roszcząca sobie prawdo do głoszenia jakiejś prawdy w końcu dążyć będzie do unicestwienia wszystkiego, co jej przeczy. Chrześcijaństwo (pojęte przednowocześnie) również może być rozpatrywane jako forma totalitaryzmu, szczególnie gdy weźmiemy

${ }^{49}$ Por. G. Vattimo, Belief, s. 55.

${ }^{50}$ Por. wystąpienie Vattimo pt. Sekularyzacja to chrześcijaństwo na konferencji Aboagora.

51 Por. G. Vattimo, Belief, s. 52.

${ }^{52}$ G. Vattimo, Poza interpretacjq, s. 12.

53 Por. G. Vattimo, Społeczeństwo przejrzyste, s. 102.

${ }^{54}$ G. Vattimo, Poza interpretacjq, s. 42.

${ }^{55}$ Por. ibidem, s. 40. Taylor zaś pisze o przemocy i religii w ten sposób: „[...] trwała ludzka podatność na fascynację śmiercią i przemocą jest w istocie manifestacją naszej natury jako homo religiosus”. Ch. Taylor, A Catholic Modernity, Oxford University Press 1999, s. 28. Wydaje się, że on również mógłby stanąć w szeregu z wymienionymi wyżej filozofami uznającymi związek religii z przemocą. 
pod uwagę inkwizycję, krucjaty czy jego opresyjny charakter zamykający usta wielu światłym ludziom. Każde z tych działań było przecież prowadzone w imię Prawdy (przez duże „P”), którą jest Bóg. Innymi słowy, Jedność zawsze prowadzi do przemocy. Dlatego ponowoczesność kojarzona będzie z pluralizmem (osłabianiem Jedności) jako dążeniem do zerwania z przemocą ${ }^{56}$. W tym kontekście chrześcijaństwo pojęte ponowocześnie łączy Vattimo z teorią Girarda ukazującą mechanizm przemocy ukryty w sacrum ${ }^{57}$, czym przesuwa nieco środek ciężkości swej interpretacji. Nie chodzi już bowiem o przemoc powodowaną metafizycznym dążeniem do prawdy absolutnej, ale o traktowanie Boga przez pryzmat orzecznika „wszechmocny” czy - używając kategorii Otta - poprzez zawarty w nim element tremendum. Bóg pojęty w ten sposób (np. w judaizmie) powoduje przemoc. Wraz z przyjściem Jezusa natomiast, który nauczył nas „nie myśleć o Bogu jako o panu, ale przyjacielu”58, czyli zerwał z pojmowaniem Boga w kategoriach mocy, zawiera się zarazem dążenie do zerwania z przemocą powodowaną przez taki paradygmat. Interpretacja Vattimo ukazuje „doktrynę, której sensem jest kenosis Boga i zbawienie rozumiane jako rozkład świętości jako naturalnie-brutalnej [natural-violent-A.T.]"59. Demitologizacja i sekularyzacja zwalczające przemoc, wpisują się zatem pozytywnie w chrześcijaństwo, w istocie są wręcz pełniejszą realizacją chrześcijańskiej prawdy ${ }^{60}$. Większa swoboda w interpretacji pisma czy rezygnacja z dogmatów, do czego również prowadzą demitologizacja i sekularyzacja, sprawia, że otwierają się horyzonty, zwiększa się liczba możliwych dróg rozumienia, więc następuje pluralizacja, która, jak stwierdziliśmy, przyczynia się do zmniejszenia przemocy.

Wyzwolenie wielości mitów, a co za tym idzie, ponowne ugruntowanie religii, niesione przez hermeneutykę, wydarza się jedynie dzięki procesowi sekularyzacji, rozpoczętemu przez opowieść o kenosis Boga we wcieleniu ${ }^{61}$ - pisze Vattimo.

To wszystko (sekularyzacja, demitologizacja, odczarowanie itd.) spowodowane jest zaś rozwojem myśli hermeneutycznej (w przypadku Vattima czerpiącej z Nietzschego i Heideggera), która zatem „stanowi rozwój i dojrzewanie chrześcijańskiego przesłania”62. Powstaje jednak pewna wątpliwość dotycząca granic interpretacji

${ }^{56}$ U Rorty’ego pluralizm staje się wręcz wartością samą w sobie, nie zaś środkiem do celu, jakim jest zerwanie z przemocą. Dlatego właśnie Vattimo podejmie krytykę etyki redeskrypcji rozwijaną przez Rorty’ego w Poza interpretacja. Por. G. Vattimo, Poza interpretacjq, rozdział III, ss. $39-54$.

${ }_{57}$ Por. R. Girard, Sacrum i przemoc, tłum. M. Plecińska, Poznań 1993.

${ }^{58}$ G. Vattimo, Belief, s. 44.

${ }^{59}$ Ibidem, s. 61.

${ }^{60}$ Por. ibidem, s. 47, a także: G. Vattimo, Poza interpretacja, s. 63; idem, After ontotheology..., s. 35.

${ }^{61}$ G. Vattimo, Poza interpretacja, s. 67.

${ }^{62}$ R. Rorty, G. Vattimo, The Future of Religion, Columbia UP 2005, s. 47. 
czy multiplikacji opisów, co postuluje hermeneutyka Vattima. Bez granic bowiem moglibyśmy popaść w całkowity relatywizm i proponować takie „interpretacje” chrześcijaństwa, które nie mają z nim nic wspólnego. Vattimo upatruje istoty chrześcijaństwa w przykazaniu miłości i z niego czyni granicę interpretacji. Dopóki bowiem zachowamy główny sens przesłania Jeuzsa, wszystkie nasze interpretacje będą „dobre”. Włoski filozof przywołuje słowa Augustyna „kochaj i rób, co chcesz”, twierdząc, że wyrażają one proponowany przez niego limit interpretacji (czyli też w tym kontekście sekularyzacji i demitologizacji) ${ }^{63}$.

Ponowoczesne chrześcijaństwo będzie dla Vattima oparte na przykazaniu miłości ogłoszonym przez Jezusa. W tym aspekcie przypomina ono nieco oświeceniowe koncepcje moralnej istoty religii ${ }^{64}$, bowiem w obu przypadkach najistotniejszym wymiarem religii będzie jej społeczne przesłanie miłości bliźniego. Ponowocześnie religia nie będzie skupiać się na aspektach kultu i obrządku religijnego, tj. na czczeniu Boga (tak jak nie miało to miejsca również w przywołanych koncepcjach moralnej istoty religii), bo Bóg, którego należy w taki sposób wysławiać i błagać Bóg-tremendum-numinosum, już „umarł”. Pozostaje nam jedynie Bóg-fascinans, którego można podziwiać i owszem, można się do niego również modlić, lecz w stosunku przyjacielskim, nie zaś poddańczym. Ponowoczesny powrót do religii, do chrześcijaństwa, będzie zatem przede wszystkim powrotem nie do Boga, ale do wartości niesionych przez religię, takich jak: solidarność, pokój, empatia i miłość (miłosierdzie) ${ }^{65}$. Na bazie tych wartości natomiast każdy wierzący musi odnaleźć „swoje” chrześcijaństwo, swoją religię, podjąć się próby interpretacji. Ponowoczesne chrześcijaństwo nie jest bowiem, jak niegdyś, solidną, metafizyczną strukturą ukazującą prawdę absolutną. Jest jedynie jedną z dróg, którą należy przemyśleć i znaleźć jej znaczenie.

Wierzyć w zbawienie - pisze Vattimo - nie będzie znaczyć podporządkowania się wszystkiemu, co napisane w Ewangelii i dogmatycznych naukach Kościoła, lecz raczej próbę zrozumienia sensu tekstów ewangelicznych dla mnie, tu i teraz ${ }^{66}$.

Zadaniem wierzącego zatem jest przemyślenie, w pojęciach sekularnych, chrześcijańskiego przesłania, jakie jest obecne w konkretnej epoce (ze względu na dziejowość panującą ponowocześnie i postawione na tej bazie twierdzenie, że sens zbawienia może być ujęty tylko historycznie $\left.{ }^{67}\right)^{68}$, dla konkretnego człowieka, w konkretnym miejscu. Inną bowiem interpretację chrześcijaństwa zaproponuje

${ }_{63}$ Por. G. Vattimo, Belief, s. 64.

${ }^{64}$ Mam tu na myśli wspomniane już koncepcje Lessinga, Kanta, czy wczesnego Hegla.

${ }^{65}$ Por. G. Vattimo, Belief, s. 56.

${ }^{66}$ Ibidem, s. 66.

67 Por. ibidem, s. 79.

${ }^{68}$ Por. ibidem, s. 75. Problem bycia katolikiem dziś porusza również Taylor: „[...] chodzi o to, [...] co to znaczy być chrześcijaninem dziś, znaleźć nasz autentyczny głos w ewentualnym katolickim chórze”. Ch. Taylor, A Catholic Modernity, s. 15. 
konkretny XX-wieczny ugandyjczyk, a inną konkretny XXI-wieczny europejczyk (przynajmniej tak powinno, wedle Vattimo, być). Co więcej, włoski filozof wydaje się widzieć w chrześcijaństwie jedyną szanse dla ludzkości - „»Nie możemy nie nazywać się chrześcijanami«, ponieważ w świecie, w którym Bóg umarł - w którym metanarracje uległy rozpadowi, a każdy autorytet został, na szczęście, zdemitologizowany, włączając w to autorytet wiedzy »obiektywnej« - jedyna szansa ludzkiego przetrwania spoczywa w chrześcijańskim przykazaniu miłości”69.

Ponowoczesna koncepcja Vattimo przedstawia rozum jako nieskonfliktowany z religią. Konflikt ten nie występuje zaś, ponieważ nastąpiło osłabienie mocnych struktur - zerwanie z metafizyką obecności, z pojęciem fundamentu, prawdy absolutnej czy z Jednością. „,Teraz, gdy Kartezjański (i Heglowski) rozum ukończył swą parabolę, nie ma sensu przeciwstawiać sobie tak ostro wiarę i rozum"70 - stwierdza Vattimo. Rozum i religia to dwa oddzielne paradygmaty, które nie wchodzą ze sobą w relację, bo dotyczą czego innego. Zarówno więc ponowocześnie pojęty rozum, jak i religia stanowią tylko jedne z wielu możliwych dróg interpretacji świata. Ponieważ zaś nie istnieje fundament, żadna ostateczna instancja, do której możemy się odwołać, nie jesteśmy w stanie stwierdzić, która z nich (lub czy w ogóle którakolwiek) w większym stopniu „dociera do prawdy”71. Zarówno bowiem z perspektywy paradygmatu rozumu, jak i paradygmatu religii można upierać się, że ten jeden konkretny jest najwłaściwszy. Z tej perspektywy można przedstawić również krótko relację nauki i religii, która w ponowoczesności nie jawi się jako konflikt z tych samych powodów, co relacja religii z rozumem - nauka i religia to oddzielne drogi interpretacji, przy czym nie można stwierdzić, która z nich jest „lepsza”72. Jeśli nauka wykazuje sprzeczność w religii albo religia w nauce, to świadczy to jedynie właśnie o tym, że są to różne od siebie drogi interpretacji świata ${ }^{73}$.

${ }^{69}$ R. Rorty, G. Vattimo, The Future of Religion, s. 54.

${ }^{70}$ G. Vattimo, Belief, s. 87.

${ }^{71}$ Podobnego zdania jest Rorty, który również nie uznaje jakiejś ostatecznej instancji. W dziele An Ethics for Today omawia on konflikt między relatywistami a fundamentalistami: „[...] walka między relatywizmem a fundamentalizmem to konflikt między dwoma wielkimi produktami ludzkiej wyobraźni. Nie jest to rywalizacja między poglądem, który jest zgodny z rzeczywistością i tym, który nie jest”. R. Rorty, An Ethics for Today, Columbia University Press 2011, s. 17. Nie ma bowiem fundamentu, do którego można się odwołać, aby stwierdzić, który z poglądów jest „lepszy” (i co to znaczy „lepszy”).

${ }^{72}$ Wydaje się, że na gruncie filozofii Vattima jedyne kryterium ustalania tego, która z interpretacji jest „lepsza”, może stanowić zawarte w niej (albo nie) dążenie do Jedności, do zawłaszczenia wszystkiego - taka interpretacja z pewnością będzie „gorsza” od tej, która dąży do pluralizmu i zakłada siebie samą jako interpretację, nie zaś jako odkrycie jakiejś prawdy absolutnej.

${ }^{73}$ Również Rorty nie postrzega relacji nauki i religii jako konfliktu i proponuje podobne do Vattima uzasadnienie, mówiąc, że nauka i religia „[...] wydają się spełniać dwa różne rodzaje pragnień. Nauka pozwala nam przewidywać i kontrolować, religia natomiast oferuje większą nadzieję, a zatem coś, dlaczego warto żyć”. R. Rorty, Religious Faith, Intellectual Responsibility and Romance, w: R.A. Putnam (red.), Cambridge Companion to William James, Cambridge 


\section{Zakończenie}

Ponowocześnie religia powróciła po długiej nieobecności spowodowanej prymatem rozumu i metafizyki obecności. Nowoczesny rozum przyczyniał się do regresu religii, zaś w ponowoczesności, dzięki krytyce prawdy obiektywnej i możliwości dystansu, filozofowie na nowo zaczęli rozważać religię. Powróciła ona jednak w innej formie. Jak zobaczyliśmy, myśliciele tacy jak Vattimo nie interesują się tymi samymi zagadnieniami, które zajmowały filozofów metafizyki obecności. Coraz większego znaczenia nabiera filozofia praktyczna, na której skupienie dobrze widać w filozofii religii Vattima. To, co istotne współcześnie, to indywidualne przeżywanie religii przez konkretnych ludzi w konkretnych miejscach i czasach, to odnajdywanie sensu religii dla konkretnych jednostek oraz praktyczne konsekwencje płynące z konkretnych wyborów w obrębie sfery religii. Zmienia się również postrzeganie Boga - zamiast wszechmocnego władcy, miłujący przyjaciel. Ponieważ zaś współcześnie człowiek posiada niemalże nieograniczoną swobodę interpretacyjną (jedyną granicą jest miłość), liczbę sposobów rozumienia religii będzie się zwiększać, co pomoże, wedle włoskiego myśliciela, przeciwstawić się przemocy. Wydaje się, że zdaniem dobrze podsumowującym prezentowany tekst będą słowa Vattima skierowane do jego ucznia kończące dzieło The Future of Religion: „[...] religia nie umarła, Santiago, Bóg wciąż jest w pobliżu”74.

\section{Literatura}

Adorno Th., Horkheimer M., Dialektyka oświecenia, tłum. M. Łukasiewicz, M. J. Siemek, Warszawa 2010.

Chlewicki M., Kant a probelm filozofii religii, Bydgoszcz 2012.

Descartes R., Medytacje o pierwszej filozofii, tłum. J. Hartman, Kraków 2004.

Gadacz T., Rozumowe poznawanie Boga, Bydgoszcz 2000.

Gadamer H.-G., Prawda i metoda, tłum. B. Baran, Warszawa 2007.

Girard R., Sacrum i przemoc, tłum. M. Plecińska, Poznań 1993.

Habermas J, Przyszłość natury ludzkiej, tłum. M. Łukasiewicz, Warszawa 2003.

Hegel G.W.F., Fenomenologia ducha, tłum. A. Landman, Warszawa 2002.

Hegel G.W.F., Życie Jezusa, tłum. M. J. Siemek, Warszawa 1995.

Husserl E., Filozofia jako ścisła nauka, tłum. W. Galewicz, Warszawa 1992.

University Press 1997, s. 89. Taylor natomiast uważa stwierdzenie, że nauka obaliła religię za zbyt proste, bowiem „[...] tym, co czyni wiarę problematyczną, często trudną i pełną wątpliwości, nie jest po prostu »nauka«”. Ch. Taylor, Closed World Structures, w: M. Wrathall (red.), Religion after Metaphysics, Cambridge University Press 2003, s. 55. Przyczyn problemów związanych z wiarą dopatruje się on bardziej we współczesnym humanizmie. Jednak na relację nauka-religia patrzy podobnie do Rorty’ego i Vattima, tzn. nie zauważa konfliktu.

${ }^{74}$ R. Rorty, G. Vattimo, The Future of Religion, s. 81. 
Kant I., Religia w obrębie samego rozumu, tłum. A. Bobko, Kraków 1993.

Kuhn T.S., Struktura rewolucji naukowych, tłum. H. Ostromęcka, Warszawa 2011.

Laertios D., Żywoty i poglądy słynnych filozofów, tłum. K. Leśniak, I. Krońska, B. Kupis, W. Olszewski, Warszawa 1984.

Lessing G.E., Wychowanie rodzaju ludzkiego, tłum. H. Kahanova, w: G.E. Lessing, Dzieła wybrane, t. III, Warszawa 1959.

Lyotard F., Kondycja ponowoczesna, tłum. M. Kowalska, J. Migasiński, Warszawa 1997.

Nietzsche F., Wiedza radosna, tłum. L. Staff, Warszawa 1906.

Otto R., Świętość, tłum. B. Kupis, Wrocław 1993.

Rorty R., An Ehtics for Today, Columbia University Press 2011.

Rorty R., Religious Faith, Intellectual Responsibility and Romance w: “Cambridge Companion to William James”, red. R. A. Putnam, Cambridge UP 1997.

Rorty R., Vattimo G., The Future of Religion, Columbia UP 2005.

Taylor Ch., A Catholic Modernity, Oxford University Press 1999.

Taylor Ch., Closed World Structures, w: M. Wrathall (red.), Religion after Metaphisics, Cambridge University Press 2003.

Taylor Ch., Maclure, J., Secularism and Freedom of Conscience, Harvard 2011.

Vattimo G., After onto-theology: philosophy between science and religion, w: M. Wrathall (red.), Religion after Metaphisics, Cambridge University Press 2003.

Vattimo G., Belief, tłum. D. Webb, Stanford University Press 1999.

Vattimo G., Koniec nowoczesności, tłum. M. Surma-Gawłowska, Kraków 2006.

Vattimo G., Postnowoczesność i kres historii, tłum. B. Stelmaszczyk, w: R. Nycz (red.), Postmodernizm. Antologia przekładów, Kraków 1998.

Vattimo G., Poza interpretacjq. Znaczenie hermeneutyki dla filozofii, tłum. K. Kasia, Kraków 2011.

Vattimo G., Społeczeństwo przejrzyste, tłum. M. Kamińska, Wrocław 2006.

Vattimo G., Ślad śladu, tłum. E. Łukaszyk, w: J. Derrida, G. Vattimo, Religia, Warszawa 1999.

Węcławski T., Wspólny świat religii, Kraków 1995. 
